\title{
EFFECTIVE BUTT JOINTS OF BAR REINFORCEMENT IN MODERN MONOLITHIC HOUSING CONSTRUCTION
}

\author{
M.V. Zavoloka, PhD., Professor, \\ Y.M. Zavoloka, Engineer, \\ I.I. Grynyova, Assistant, \\ irene.grinyova@gmail.com, ORCID: 0000-001-7637-6029 \\ Y.V. Zavoloka, Associate Professor \\ Odessa State Academy of Civil Engineering and Architecture \\ mvzavoloka@ukr.net
}

\begin{abstract}
The research of national and foreign achievements in the technology of joining reinforcing bars of the periodic profile, which ensure the continuity of the formation of reinforcing cages in the monolithic housing construction, has been carried out. It has been found that in Ukraine, according to the current regulatory documents, in the usual conditions and in seismic areas, two main methods of joining the bar reinforcement are used: overlap (without welding and welded) with the most demanded welded method. Summarized conclusions and recommendations are given.
\end{abstract}

Keywords: reinforcing bar, reinforcing cage, mechanical joining, coupling, tapered thread, cylindrical thread, fixing, innovative technologies.

Introduction. The main trends in modern methods of improving the splicing of rebars of the periodic profile for monolithic housing construction indicate the transition from traditional splicing techniques to innovative, reliable, mechanic ones, which are based on the principle of coupling connections. It has been established that the use of mechanical connections, especially reinforcement for labor costs, steel consumption and a higher level of fire safety in the construction and reconstruction of buildings, ensures the continuity of the formation of reinforcing cages.

This mechanical connection of reinforcement can be recommended in a building site in seismic areas with a seismicity of 7-9 points.

Analysis of previous studies. Tests have been carried out on standard types of connection (A12) and positional types of connection (P13). Coupling joint samples have been tested for tension in accordance with the requirements of GOST 12004 [1]. The research has established that deformability of connections, or in other words backlash of the connection did not exceed $0.1 \mathrm{~mm}$ when the rod $0,6 \sigma t$ tensile stress, tensile bond strength exceeded the rejection value of tensile strength of the reinforcing bar.

Two types of resolution are characteristic for the tested samples: breakage of the reinforcing bar and thread failure, i.e. cutting the thread on the reinforcing bar followed by pulling it out of the coupling. All types of connections on which the tests were carried out are classified as compressedtensioned connections, i.e. such connections that can perceive and compressive and tensile forces. The strength of threaded connections is directly dependent on the length of screwing and the mechanical characteristics of the elements being joined. Estimating the test results it should be noted that the strength of threaded connections is not inferior to the strength of the whole rod.

The purpose of the study. To summarize the results of foreign achievements and their implementation in order to create reliable and highly efficient methods of joining reinforcement in modern monolithic housing construction for the purpose of application in our country.

Objects and methods of the research. The objects of the research are the types of splicing of reinforcing bars of a periodic profile, which create a continuity of the formation of reinforcing cages for the reinforcement of reinforced concrete structures. 
Methods of the research - the analysis of the advantages and disadvantages of the existing technologies of splicing fittings produced in a construction site has been carried out in comparison with the innovative technology of mechanical splicing.

The results of the research. During the construction of buildings and structures from precast concrete, the problem of joining reinforcement bars on the construction site was absent. But over the past decade, due to the widespread mass transition to the construction of buildings and structures made of monolithic reinforced concrete using the new effective high-strength thermomechanically reinforced reinforcement class A500C with a European (sickle-shaped) double-row periodic profile according to DSTU [2], the problem of reinforcement bar joint has become topical. While designing and constructing multi-storey and high-rise buildings from monolithic reinforced concrete, the problem of rapid and reliable connection of reinforcement bars arises, since the length of the reinforcement delivered to the construction site is limited by transport conditions and generally does not exceed $12 \mathrm{~m}$.

In our country, according to the current regulatory documents [2-4] for the design and construction of reinforced concrete structures of buildings and structures under normal conditions and in seismic areas [5], there are mainly two main methods for joining bar reinforcement: overlap joining without welding and welded.

The simplest one that does not require special equipment and is quite reliable is the overlap joint. But this method of joining has significant drawbacks, and its area of application is rather limited. The strength and reliability of the joint overlap without welding is ensured by adhesion to the concrete, and this requires a large bypass of the rods, which leads to overspending of the reinforcement. Also, in order to guarantee strength in the overlap zone, additional setting of transverse reinforcement is necessary. As a result of the overlap joint in the structure, densely reinforced zones appear, which complicates the laying of the concrete mix.

The disadvantage of this method of joining is the misalignment of the joining of rod reinforcement, where the rods are installed with eccentricity.

While using the overlap joining the transfer of force from one rod to another through the surrounding concrete and the destruction of the protective layer of concrete in the overlap zone can subsequently lead to the complete destruction of the structure.

It has been established that overlapping with length from $20 \mathrm{~d}$ to $40 \mathrm{~d}$, depending on the operating conditions of the reinforcement and the quality of the joints in one section, leads to a loss of $3.5 \%$ to $27 \%$ of reinforcement with its diameters from 10 to $40 \mathrm{~mm}$ and a length of connecting rods $6.0 \mathrm{~m}[6]$.

The overlapping of reinforcement rods is forbidden to be placed in areas of concentrated load application and in places of the greatest stress.

In the construction of buildings in seismic areas, according to the standards [7], it is necessary to fulfill a number of additional design requirements that limit the use of overlapping joints or increase the overlap length.

The overlap weldings have a shorter bypass length, they are more efficient, but require highly skilled welding workers. Overlap joining (without welding and welded) is technically difficult to perform in reinforced concrete structural members with high reinforcement saturation.

In the regulatory documents $[8,9]$ there are no requirements for welding of reinforcing bar with a strength class of $500 \mathrm{~N} / \mathrm{mm}^{2}$, since during the creation of these documents, such rolled products were not mass produced by the metallurgical industry.

The use of welded joints increases the cost and complexity of reinforcement work due to the need for high power consumption, requires the involvement of highly skilled welders and sophisticated quality control.

Instead of the traditional types of joining of a rod-shaped rebar of a periodic profile in most economically developed countries of the world, such as the USA, Canada, Great Britain, Germany, etc., in recent years only mechanical connections have been used with the help of special couplings.

At present, mechanical connections of fittings produced in the conditions of a construction site have been carried out using threaded couplings with conical (Fig. 1) and cylindrical (parallel) (Fig. 2) threads and using compression joints (Fig. 3). 


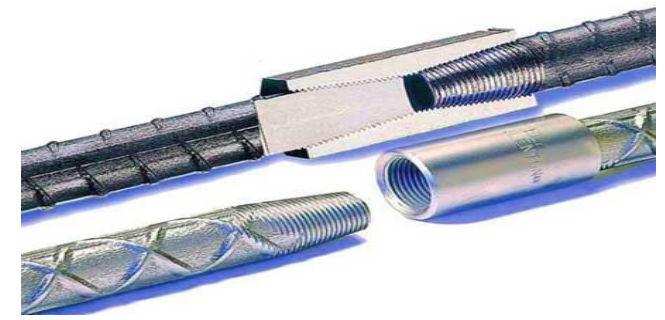

Fig. 1. Coupling with tapered thread LENTON US company ERICO

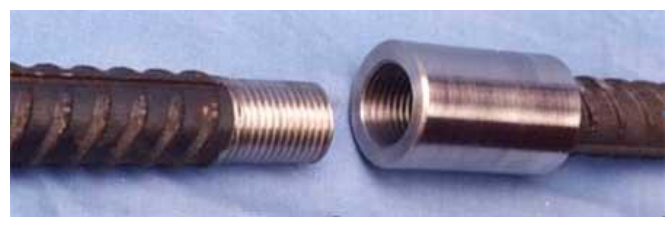

Fig. 2. Coupling with a cylindrical (parallel) thread BARTEC company DEXTRA

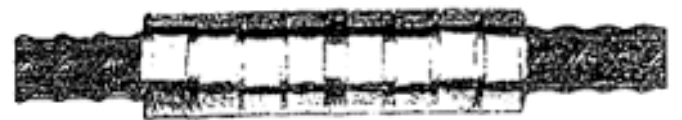

Fig. 3. General view of the pressurized coupling

Coupling joints have shown their effectiveness, since they ensure a high-quality, reliable joint, work is significantly reduced, a special qualification of workers is not required, and the duration of joining is reduced.

Experimental studies have shown that the duration of splicing the "stretched" joint by pressurized reinforcement with a diameter of $32-40 \mathrm{~mm}$ on the equipment of the Sprut company is about 20 minutes, the production time of the screw connection of the LENTON firm with a tapered thread is less than 10 minutes.

For the mechanical connection of BARTEC, according to the Guidelines [10], the rebar passes through three stages of preliminary preparation. The first stage - trimming the end of the rod at a right angle; the second stage - by means of cold heading, an increase in the initial outer diameter of the rod end, on which the thread will be cut, is made; the third stage is threading the required length at the enlarged end of the rebar. By increasing the diameter of the end of the rod by cold heading, the weakening of the cross section after threading does not occur.

For threading: conical, cylindrical (parallel), mobile thread-cutting machines are used, which can cut the necessary threads on the rebar within 5 minutes.

Connections using pressure couplings are widely used in modern construction. For rods of a periodic profile with a nominal diameter of 16 to $40 \mathrm{~mm}$ of $\mathrm{A} 400 \mathrm{C}$ and A500C classes, it is advisable to use crimped couplings

The company Sprut-Ukraine works successfully in our country on the application of joining of the reinforcement by crimping couplings.

This method involves compression of the metal coupling using a portable hydraulic tool consisting of a pumping station, a squeezing press and replaceable dies for each coupling parameter.

In Ukraine technical specifications for mechanical connections of reinforcing rods by crimping couplings [11], as well as technical specifications for connecting couplings [12], and guidelines for mechanical connections of reinforcing rods by crimping couplings [13] were introduced in 2008.

These regulatory documents have been developed by Sprut-Ukraine and approved by the Ministry of Regional Development of Ukraine.

The main purpose of the use of mechanical connections is to increase reliability, and not to obtain savings. The main advantage of mechanical connections is their industrialism and the exclusion of welding work at the construction site. 
In Ukraine, mechanical coupling fittings with a tapered thread LENTON produced by the American company ERICO have received the greatest interest.

The mechanical connection technology of reinforcing bars of a periodic profile with LENTON tapered couplings is considered to be one of the most progressive worldwide. With its use, in particular, unique buildings, masterpieces of modern construction art were built: the doubletopped skyscraper of the PETRONAS oil concern (Malaysia), the height of each is 452 meters and the Burj Dubai super-skyscraper, currently the tallest building in the world, height -823 meters.

Connections LENTON have a multi-directional tapered thread, which eliminates the possibility of its damage before the full engagement of the thread is achieved. Studies conducted in Europe, America $[14,15]$ and practical experience have shown that, after joining with the LENTON system, the rebar works as a single unit, providing "full strength" in tension, compression and in the case of alternating stresses. LENTON self-centering design with a tapered thread provides full force transmission using a coupling of minimum diameter and length.

According to technical requirements [16-19], the deformability of LENTON joints should not exceed $0.1 \mathrm{~mm}$. Since a large deformability leads to an unacceptable width of crack opening in the operational stage of reinforced concrete elements. Couplings for mechanical connection of reinforcing bars are designed for nominal values of yield strength up to $550 \mathrm{MPa}$ and values of ultimate tensile strength up to $750 \mathrm{MPa}$.

Coupling connections on a design are subdivided into the following types: standard, transitional, position, welded, bolted, trailer.

Standard types are designed to connect rods of the same diameter, when one of the joined rods can rotate freely, and its movement in the axial direction is not limited (Fig. 4, a).

Transition types are designed to connect rods of different diameters (Fig. 4, b).

Position types are designed to connect curvilinear, curved reinforcing bars of the same diameter, when none of the joined bars can rotate freely (Fig. 4, c).

Welded types are designed to connect reinforcing bars with a rolling profile or plate (Fig. 4, d).

Bolted types are designed to connect supporting steel structures with reinforced concrete foundations, columns and walls (Fig. 4, f).

End anchors are intended for anchoring of reinforcing bars in reinforced concrete structures (Fig. 4, e).

a)

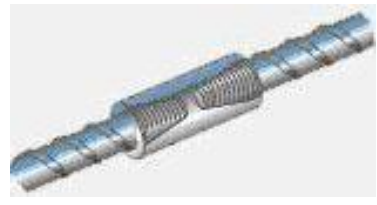

d)

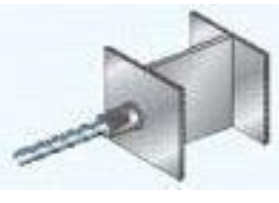

b)

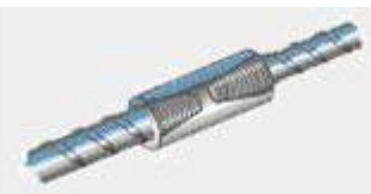

e)



c)

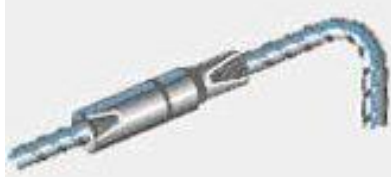

f)

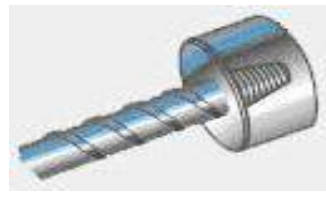

Fig. 4. Types of construction of coupling connections LENTON by ERICO:

$\mathrm{a}$ - connection of rods of the same diameter; $\mathrm{b}$ - connection of rods of different diameters; $\mathrm{c}$ - connection of curvilinear, bent reinforcing bars of the same diameter; $d$ - connection of reinforcing bars with a rolling profile or plate; $\mathrm{e}$ - connection of bearing steel structures with reinforced concrete foundations, columns and walls; $\mathrm{f}$ - end anchor for rebar in reinforced concrete structures

Threaded couplings should be used for joining reinforcement bars of a periodic profile, classes A400C ... A600C with a diameter of 12 to $40 \mathrm{~mm}$.

Since 2008, The Aviabudservice company, the official distributor of the American company ERICO, has begun to work effectively in the construction market of Ukraine to promote the technology of mechanical coupling fittings for fittings with a tapered thread LENTON. 
The work was carried out comprehensively with all the tests, obtaining the necessary evidence and conclusions. In Ukraine, the laboratory of fittings of the State Research Institute of Building Constructions conducted its own tests of strength and deformability of coupling joints of fittings A400C and A500C with a tapered thread LENTON.

In Fig. 5 and Fig. 6 examples of mechanical connections of reinforcing bars using threaded couplings of the LENTON system of the American company ERICO are shown.

In Fig. 5 the prepared couplings for further joining by reinforcing rods and the already joined rods with the couplings are shown. Fig. 6 shows the mechanical coupling of the working reinforcement of the column.

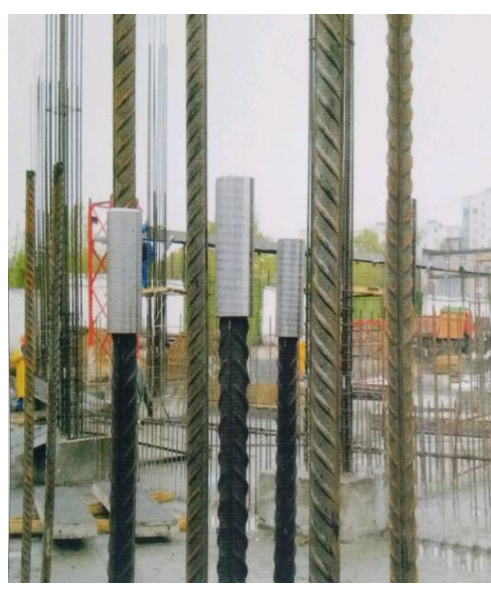

Fig. 5. Mechanical connections LENTON (connection and extension of reinforcing bars)

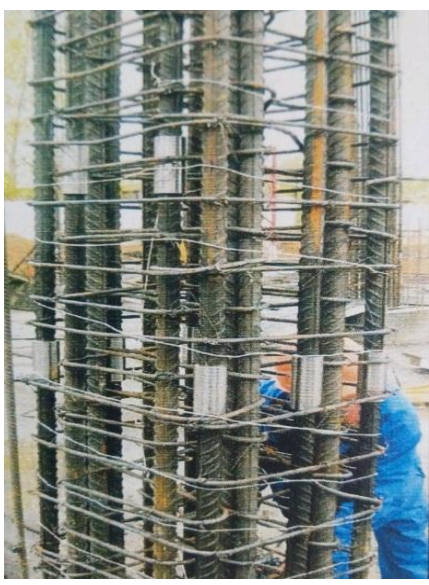

Fig. 6. Mechanical connections of LENTON reinforcement bars of the column

In the laboratory of the Research Institute for Concrete and Reinforced Concrete fittings (Moscow), studies of strength and deformability of threaded connections with a conical thread LENTON of the ERICO company and with a cylindrical (parallel) thread BARTEC of the DEXTRA company with a class A500C reinforcement with diameters of $\varnothing 12, \varnothing 25, \varnothing 40 \mathrm{~mm}$ were conducted.

2-3 twin samples were tested. Tables 1, 2 show the mechanical properties of some samples of mechanical connections [18]. Also, tests were carried out on samples taken from various construction sites, both for certification and for quality control.

Table 1 - Mechanical connections LENTON

\begin{tabular}{|c|c|c|c|c|}
\hline \multirow{2}{*}{$\begin{array}{c}\text { Diameter, } \\
\mathrm{mm}\end{array}$} & $\begin{array}{c}\text { Yield strength } \\
\sigma_{\mathrm{T}}\left(\sigma_{0,2}\right)\end{array}$ & $\begin{array}{c}\text { Temporary } \\
\text { resistance } \sigma_{\mathrm{B}}\end{array}$ & $\begin{array}{c}\text { Relative extension } \\
\sigma_{\mathrm{p}}, \%\end{array}$ & $\begin{array}{c}\text { Deformability at } \\
\text { stretching } \Delta, \mathrm{mm}\end{array}$ \\
\cline { 2 - 3 } & \multicolumn{2}{|c|}{$\mathrm{H} / \mathrm{mm}^{2}$} & 5,7 & 0,005 \\
\hline 12 & 560 & 625 & 4,3 & 0,012 \\
\hline 12 & 555 & 619 & 6,0 & 0,018 \\
\hline 12 & 543 & 618 & 5,8 & 0,071 \\
\hline 25 & 573 & 659 & 5,9 & 0,015 \\
\hline 25 & 583 & 661 & 5,9 & 0,009 \\
\hline 25 & 578 & 666 & 4,9 & 0,003 \\
\hline 40 & 543 & 629 & 8,2 & 0,004 \\
\hline 40 & 569 & 677 & 5,0 & 0,009 \\
\hline 40 & 551 & 636 & & \\
\hline
\end{tabular}


Table 2 - Mechanical Connections BARTI EC

\begin{tabular}{|c|c|c|c|c|}
\hline $\begin{array}{c}\text { Diameter, } \\
\mathrm{mm}\end{array}$ & $\begin{array}{c}\text { Temporary resistance } \\
\sigma_{\mathrm{B}}, \mathrm{H} / \mathrm{mm}^{2}\end{array}$ & $\begin{array}{c}\text { Deformability at } \\
\text { stretching } \Delta, \mathrm{mm}\end{array}$ & $\begin{array}{c}\text { Relative } \\
\text { extension } \sigma_{\mathrm{p}}, \%\end{array}$ & $\begin{array}{c}\text { Nature of } \\
\text { destruction }\end{array}$ \\
\hline 12 & 663 & 0,036 & 8 & along the rebar \\
\hline 12 & 628 & 0,065 & 7 & same \\
\hline 25 & 693 & 0,100 & 9 & same \\
\hline 25 & 691 & 0,022 & 8 & same \\
\hline 40 & 717 & 0,084 & 7 & same \\
\hline 40 & 691 & 0,083 & 8 & same \\
\hline
\end{tabular}

As a result of the research it was established:

1) the average value of the deformability of threaded joints was $0.038 \mathrm{~mm}$, therefore, there is no possibility of shifting the reinforcing bars in the coupling and, as a result, there will be no cracks on the concrete surface;

2) the average value of the uniform elongation of the reinforcing bars after breaking the connections was $7.8 \%$, and when security is $\mathrm{P}=0.95-4.2 \%$, which indicates a high energy intensity of adhesion of the reinforcing bar to the coupling and this is an important factor that increases the reliability of the design and its resistance to progressive destruction [19].

As a result of the research work carried out and taking into account international experience in Ukraine, the national standard DSTU-NBV.2.6-155: 2010 "Guidelines for the use of coupling joints for fittings with tapered threads in the design and manufacture of reinforced concrete structures " [20] was developed.

At present, the technology of mechanical coupling connections for fittings with a tapered thread LENTON has firmly taken its place in the domestic monolithic construction.

\section{Summary:}

1. For the first time in Ukraine, the National Standard for threaded mechanical fittings of reinforcement was developed and put into effect, where the requirements for strength and deformability of joints, geometrical dimensions of coupling connections and areas of their application are indicated.

2. The use of mechanical connections, as the main method, of joining reinforcing bars of $\mathrm{A} 400 \mathrm{C}$ and $\mathrm{A} 500 \mathrm{C}$ classes in monolithic reinforced concrete structures will continuously grow.

\section{References}

[1] Stal' armaturnaya. Metody ispytaniya na rastyazheniye: GOST 12004-8. M.: 1982.

[2] DSTU 3760:2006. Prokat armaturnyy dlya zalizobetonnykh konstruktsiy. Zahal'ni tekhnichni umovy. (ISO 6935-2:1991,NEQ). K.: 2007.

[3] DBN V.2.6-98:2009. Konstruktsiyi budynkiv i sporud. Betonni ta zalizobetonni konstruktsiyi. Osnovni polozhennya proektuvannya. K.: 2011.

[4] DSTU BV.2.6-156:2010. Konstruktsiyi budynkiv i sporud. Betonni ta zalizobetonni konstruktsiyi z vazhkoho betonu. Pravyla proektuvannya. K.: 2011.

[5] DBN V.1.1-12:2014. Budivnytstvo u seysmichnykh rayonakh Ukrayiny. K.: 2014.

[6] S.A. Madatyan, "Sovremennyye materialy i tekhnologii armaturnykh rabot", Beton $i$ zhelezobeton, vol. 3, pp.12-17, 2016.

[7] DSTU BV.2.6-168:2011. Armaturni ta zakladni vyroby zvarni, z"yednannya zvarni armatury ta zakladnykh vyrobiv $\mathrm{v}$ zalizobetonnykh konstruktsiy. Zahal'ni tekhnichni umovy. (HOST 10922-90, MOD). K.: 2012.

[8] DSTU BV.2.6-169:2011. Z"yednannya zvarni armatury ta zakladnykh vyrobiv zalizobetonnykh konstruktsiy. Typy, konstruktsiyi ta rozmiry (HOST 14098-91, MOD). K.: 2012.

[9] Rukovodstvo po primeneniyu mekhanicheskikh soyedineniy «BARTEC» proizvodstva firmy «DEXTRA». 2003. 
[10] Mekhanichni z"yednannya armaturnykh sterzhniv opresovuvannyam muft. Tekhnichni umovy. TU UV 2.8-45.2-35641811-011:2008. K.: 2008.

[11] Mufty z"yednuval'ni dlya armaturnykh stryzhniv. Tekhnichni umovy. TU UV 2.7-45.235641811-002:2008. K.: 2008.

[12] Metodychni rekomendatsiyi iz mekhanichnoho z'yednannya armaturnykh sterzhniv opresuvannyam muft. K.: 2008.

[13] Mechanical connection of reinforcing bars reported by ACI Committee 439, 1999.

[14] Steels for the reinforcement of concrete - Reinforcement couplers for mechanical splices of bars - Part 1: Requiments (final draft): ISO / EDIS 15835-1:2008 (E). Geneva: ISO, 2008 (International Standard).

[15] Rukovodstvo po primeneniyu mekhanicheskikh soyedineniy «LENTON» proizvodstva korporatsii «ERICO». 2003.

[16] Rekomendatsii po mekhanicheskim soyedineniyam armaturnoy stali dlya zhelezobetonnykh konstruktsiy RA-10-1-04. Assotsiatsiya «Zhelezobeton». M.: 2004.

[17] Tekhnicheskiye Usloviya. Soyedineniye armatury mekhanicheskiye «LENTON» proizvodstva firmy ERICO. TU 4842-196-46854090-2005. M.: NIIZHB, 2005.

[18] V.V. D'yachkov, "Prochnost' i deformativnost' rez'bovykh mekhanicheskikh soyedineniy armatury", Beton i zhelezobeton, vol. 1, pp. 11-14, 2009.

[19] V.V. D'yachkov, "Mekhanicheskiye soyedineniya armatury-primeneniye i tendentsiya razvitiya", Beton i zhelezobeton, vol. 4, pp. 8-9, 2013.

[20] Nastanova z zastosuvannya mekhanichnykh muftovykh z"yednan' armatury z konichnoyu rizzyu pry proektuvanni i vyhotovlenni zalizobetonnykh konstruktsiy: DSTU N B V.2.6155:2010. K.: 2011.

\title{
ЕФЕКТИВНІ СТИКОВІ З'ЄДНАННЯ СТРИЖНЕВОЇ АРМАТУРИ В СУЧАСНОМУ МОНОЛІТНОМУ ДОМОБУДІВНИЦТВІ
}

\author{
М.В. Заволока, к.т.н., професор, \\ Ю.М. Заволока, інженер, \\ Гриньова I.I., асистент, \\ irene.grinyova@gmail.com, ORCID: 0000-001-7637-6029
}

Ю.В. Заволока, доцент

Одеська державна академія будівництва та архітектури mvzavoloka@ukr.net

\begin{abstract}
Анотація. Проведено дослідження вітчизняних і зарубіжних досягнень в технології стикування арматурних стрижнів періодичного профілю, які забезпечують безперервність формування арматурних каркасів при монолітному житловому будівництві. Виявлено, що в Україні, згідно з чинними нормативними документами в звичайних умовах і в сейсмічних районах застосовують два основних способи стикування стрижневої арматури: внапуск беззварений i зварений спосіб. Найбільш простим, який не вимагає спеціального устаткування i достатньо надійний $\epsilon$ стик внапуск, але в конструкції виникають густоармовані зони, що ускладнює укладання бетонної суміші. Даний тип стикування стрижневої арматури внапуск заборонено розташовувати в зонах концентрованого прикладання навантаження і в місцях найбільшого напруження. Зварні стикування внапуск більш ефективні, однак вимагають високої кваліфікації робітників-зварювальників.

Натомість традиційним типам стикування стрижневої арматури періодичного профілю в більшості економічно розвинених країнах світу, таких як США, Канада, Великобританія, Німеччина та тощо в останні роки застосовують тільки механічні з'єднання за допомогою спеціальних муфт.

Головною метою застосування механічних з'єднань є підвищення надійності, а не отримання економії. Головною перевагою механічних з'єднань $\epsilon$ їх індустріальність i
\end{abstract}


виключення зварювальних робіт на будмайданчику.

В результаті проведеного компанією «Авіабудсервіс» випробування міцності і деформативності муфтових з'єднань арматури класів А400С i А500С i з урахуванням зарубіжного досвіду в Україні технології механічного муфтового з'єднання арматури 3 конічною різьбою LENTON, визначено переваги та недоліки застосування традиційних типів стикування арматури і наведені інноваційні технології механічного стикування за допомогою різьбових муфт 3 конічним та циліндричним різьбленням, а також за допомогою опресованних муфт. Дано узагальнені висновки та рекомендації.

Ключові слова: арматурний стрижень, арматурний каркас, механічне стикування, муфта, конусна різьба, циліндрична різьба, опресування, інноваційні технології.

\title{
ЭФФЕКТИВНЫЕ СТЫКОВЫЕ СОЕДИНЕНИЯ СТЕРЖНЕВОЙ АРМАТУРЫ В СОВРЕМЕННОМ МОНОЛИТНОМ ДОМОСТРОЕНИИ
}

\author{
М.В. Заволока, к.т.н., профессор, \\ Ю.М. Заволока, инженер, \\ И.И. Гринева, ассистент, \\ irene.grinyova@gmail.com, ORCID: 0000-001-7637-6029
}

Ю.В. Заволока, доцент

Одесская государственная академия строительства и архитектурь mvzavoloka@ukr.net

Аннотация. Проведено исследование отечественных и зарубежных достижений в технологии стыковки арматурных стержней периодического профиля, обеспечивающих непрерывность формирования арматурных каркасов при монолитном домостроении. Выявлено, что в Украине, согласно действующим нормативным документам в обычных условиях и в сейсмических районах применяют два основных способа стыковки стержневой арматуры: внахлестку бессварным и сварным способом. Наиболее простым, не требующим специального оборудования и достаточно надежным является стык внахлест, но в таких конструкциях возникают густоармированных зоны, что затрудняет укладку бетонной смеси. Данный тип стыковки стержневой арматуры внахлест запрещено располагать в зонах концентрированного приложения нагрузки и в местах наибольшего напряжения. Сварные стыковки внахлест более эффективны, однако требуют высокой квалификации рабочих-сварщиков.

Традиционным типом стыковки стержневой арматуры периодического профиля в большинстве экономически развитых странах мира, таких как США, Канада, Великобритания, Германия и т.д. в последние годы применяют только механические соединения с помощью специальных муфт.

Главной целью применения механических соединений является повышение надежности, а не получение экономии материалов. Главным преимуществом механических соединений является их индустриальность и исключение сварочных работ на стройплощадке.

В результате проведенного компанией «АвиаБудСервис» испытания прочности и деформативности муфтовых соединений арматуры классов А400C и А500C, и с учетом зарубежного опыта в Украине технологии механического муфтового соединения арматуры с конической резьбой LENTON, определены преимущества и недостатки применения традиционных типов стыковки арматуры и приведены инновационные технологии механической стыковки с помощью резьбовых муфт с конической и цилиндрической резьбой, а также с помощью опрессованных муфт. Даны обобщенные выводы и рекомендации.

Ключевые слова: арматурный стержень, арматурный каркас, механическое стыкование, муфта, конусная резьба, цилиндрическая резьба, опрессовывание, инновационные технологии.

Стаття надійшла 28.02.2019 